\section{Becker nevus on the neck with ear involvement}

\author{
Khalid Mohammad Al Aboud \\ Department of Dermatology, King Faisal \\ Hospital, Makkah, Saudi Arabia
}

\section{Abstract}

This is a concise observation of Becker nevus located on the right side of the neck with involvement of the ear.

\section{Case Report}

A 30-year old man presented with a hyperpigmented patch on the right side of the neck that extended to the right ear (Figure 1). The lesion appeared during adolescence and gradually increased in size. No increase in hairs were observed in the lesion. There was no history of preceding drug intake nor associated systemic diseases. Skin biopsy showed hyperpigmentation of basal cell layer on histopathology and there were smooth muscles in the dermis. The picture was consistent with Becker nevus. Becker nevus (BN) is an uncommon cutaneous hamartoma. It usually presents in adolescence as a unilateral, hyperpigmented, hairy patch or plaque, often seen on the upper trunk..$^{1-4}$

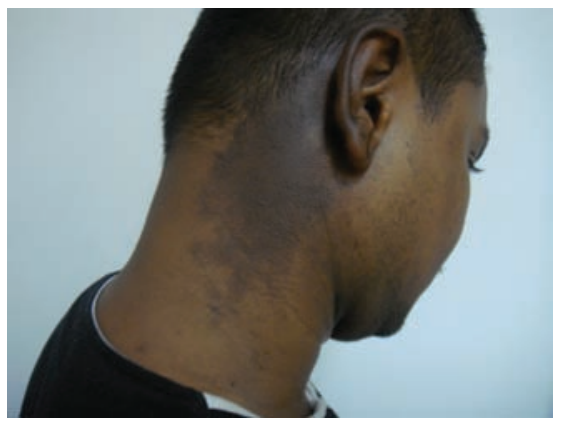

Figure 1. Becker nevus on the right side of the neck extending to the right ear.

BN may involve other sites in the body like the head or the limbs. Cephalic BN may present with asymmetrical growth of beard hairs. ${ }^{4}$

Alfadley et al.,${ }^{3}$ reported 12 cases of BN with atypical features. Only one of them was a female with BN involving the left side of the neck. It was associated with hypertrichosis. AlGhamdi et al., ${ }^{2}$ reported 11 cases with atypical features; only one of them that involved the chin and neck was a 5 -year-old boy with BN. It was also associated with hypertrichosis.

None of the above two cases involved the ear. The present case is different as it involved the external ear and was not associated with hypertrichosis.

In contrast to widely held belief, I concur with others ${ }^{2,3}$ that cases of BN in atypical locations like the neck are not uncommon and may be under-reported.
Correspondence: Khalid Al Aboud, P.0 Box 5440, Makkah, Saudi Arabia.

Tel. +966.2.5566411 - Fax +966.2.5563523/5574350.

E-mail: amoa65@hotmail.com

Key words: Becker nevus, head, skin.

Received for publication: 12 January 2011. Accepted for publication: 22 February 2011.

This work is licensed under a Creative Commons Attribution 3.0 License (by-nc 3.0).

(C) Copyright K.M. Al Aboud, 2011

Licensee PAGEPress, Italy

Dermatology Reports 2011; 3:e3

doi:10.4081/dr.2011.e3

\section{References}

1. Al Aboud K, Al Hawsawi K. Becker nevus on the hand. Eur J Dermatol 2002;12:588.

2. AlGhamdi KM, AlKhalifah AI, AlSheikh AM, AlSaif FM. Clinicopathologic profile of Becker's melanosis with atypical features. J Drugs Dermatol 2009;8:745-8.

3. Alfadley A, Hainau B, Al Robaee A, Banka N. Becker's melanosis: a report of 12 cases with atypical presentation. Int J Dermatol 2005;44:20-4.

4. Kiliç A, Kaya I, Gül U, et al. Becker nevus on face with asymmetrical growth of beard hair. J Eur Acad Dermatol Venereol 2008; 22:246-7. 